\title{
The use of the Fourier Transform Infrared spectroscopy to determine adulterants in raw milk
}

\author{
Laerte Dagher Cassoli ${ }^{1}$, Beatriz Sartori ${ }^{2}$, Paulo Fernando Machado ${ }^{1}$
}

\footnotetext{
${ }^{1}$ Clínica do Leite - ESALQ - Universidade de São Paulo.

2 FMVZ - Universidade de São Paulo.
}

\begin{abstract}
The objective of this study was to develop calibrations to determine the concentration of some milk adulterants by using the automated methodology of Fourier Transform Infrared (FTIR). For construction of calibrations, samples were collected from 100 farms in the states of São Paulo and Minas Gerais. Samples were tainted with three different adulterants commonly used in the adulteration of raw milk: sodium bicarbonate (SB), sodium citrate (SC) and cheese whey (W). Each adulterant was used at three different concentrations (SB: 0.05, 0.10 and 0.25\%; SC: 0.025, 0.050 and 0.075\% and W: 5, 10 and 20\%). For validation, 60 samples were collected in other farms, which were not considered at the development stage of calibration. Adulterants were added at the following concentrations: 0.03, 0.06, 0.10 and 0.12\% for SB; 0.02, 0.04, 0.06 and $0.08 \%$ for SC and 5, 10 and 20\% for W. Performance of each calibration was evaluated in terms of accuracy (Se), detection limit (DL) and determination coefficient $\left(\mathrm{R}^{2}\right)$. All calibrations presented $\mathrm{R}^{2}$ higher than 0.91 with $\mathrm{DL}$ of $0.015 \%$; 0.017\% and 3.9\% for SB, SC and W, respectively. Accuracy was $0.005 \%, 0.009 \%$ and $2.26 \%$ for SB, SC and W, respectively. Results show that the FTIR methodology can be used for determining the concentration of sodium bicarbonate, sodium citrate and whey in raw milk. Associated with automated equipment, it is a viable option for monitoring these adulterants, having low operational costs and high analytical performance as additional features.
\end{abstract}

Key Words: milk analysis, non-acid whey, sodium bicarbonate, sodium citrate, tainted milk

\section{Introduction}

One of the most important facts for the dairy sector was the approval of the Instrução Normativa 51 (IN-51), from Ministério de Agricultura (MAPA), which determined new variables for evaluation of the quality of raw milk for establishments with Federal Inspection Service (SIF). According to IN-51, analyses of total bacterial count (TBC), somatic cells count (SCC), composition (fat, protein, lactose) and residues of antibiotics (ATB) should be done monthly in one of the official laboratories of the Rede Brasileira de Laboratórios de Controle da Qualidade do Leite - RBQL (Brasil, 2002). On the other hand, some industries began to encourage the improvement of milk quality from its suppliers through the adoption of programs to enhance the quality of milk (Machado \& Cassoli, 2008).

Publications of RBQL indicate that the milk produced in Brazil has low microbiological quality when compared with the milk produced in other countries (Machado \& Cassoli, 2008). In a survey conducted by Cassoli \& Machado (2007), it was estimated that $40 \%$ of 28,000 producers monitored by one of the laboratories of RBQL would not meet the maximum limit of 100 thousand cfu/mL required for 2011. In this scenario of strong economic pressure and low microbiological quality of milk, the practice of adulteration of raw milk becomes a risk for the entire production chain.

There are methods that are capable of identifying the majority of adulterants. However, they have low analytical performance, require the use of reagents and are highly labor dependent (Harding, 1995; Ashurst \& Dennis, 1998). These characteristics hamper the implementation of monitoring programs in large scale. In this context, studies have demonstrated the high potential of the utilization of the methodology of Fourier Transform Infrared (FTIR) in the control of quality and monitoring of the authenticity of raw milk (Gunasekaran \& Irudayraj, 2000; Karoui \& Baerdemaeker, 2007). This methodology is already used to determine the components of milk (Leifier et al., 1996). Likewise, other compounds such as tetracycline, vegetable fat, urea, melamine and glucose may also be identified, and their concentrations determined (Sivakesava \& Irudayraj, 2002; Chen et al., 2008).

The objective of this study was to develop calibrations to determine the concentration of adulterants such as sodium bicarbonate, sodium citrate and whey in automated equipment of Fourier Transform Infrared (FTIR). 


\section{Material and Methods}

The selection of samples that show variations in their chemical composition and consequently spectral changes for a construction of robust calibration in FTIR equipment (Soyeurt et al., 2009) is necessary. Factors affecting this variability such as geographical location, time of the year and breed were considered in the sample plan. One hundred samples were collected from farms located in the states of São Paulo and Minas Gerais. Samples, from each farm were collected from bulk tanks in flasks of $1 \mathrm{~L}$ with bronopol preservative added ( $8 \mathrm{mg}$ for $40 \mathrm{~mL}$ of milk). The bulk tank milk was homogenized for 5 minutes before collecting of samples. Samples were kept refrigerated $\left(<6^{\circ} \mathrm{C}\right)$ and sent to the laboratory (Clínica do Leite da ESALQ/USP) in 24 hours.

Three adulterants were added: sodium bicarbonate (SB), sodium citrate (SC) and whey (SO), commonly used in the adulteration of raw milk (Cerdán et al., 1992; Veloso et al., 2002). For each adulterant, three different concentrations were used: $0.05 ; 0.10$ and $0.15 \%$ for sodium bicarbonate; $0.025 ; 0.05$ and 0.075 for sodium citrate; and 5, 10 and $20 \%$ for whey.

Ten $\mathrm{mL}$ of liquid rennet in 5 liters of raw milk were placed in water-bath at $32{ }^{\circ} \mathrm{C}$ for 60 minutes to obtain the whey. After this period, the mass was cut, stirred and left to drain. The collected whey was heated until the beginning of boiling to inactivate the enzyme rennet.

A sample from each farm was homogenized and subdivided into a sample of $50 \mathrm{~mL}$ without addition of adulterant (control treatment), six subsamples of $100 \mathrm{~mL}$ for the addition of sodium bicarbonate or sodium citrate and three more subsamples of 60,90 , and $95 \mathrm{~mL}$ for the addition of whey to make up the original $100 \mathrm{~mL}$. Samples were kept refrigerated and were analyzed three days after the adulteration to simulate the time that they are usually analyzed by the laboratories of RBQL (Cassoli et al., 2010).

Analyses were done in MilkoScan FT+ 6000 (Foss Analytical) equipment, which adopts the method of FTIR, in duplicate. Readings were performed in the mid-infrared with wavelengths from 3 to $10 \mu \mathrm{m}\left(1,000-5,000 \mathrm{~cm}^{-1}\right)$, and spectrums were exported and stored in electronic files (Foss Analytical, 2008). As recommended by the manufacturer, an equalization of the equipment was done every month to ensure the standardization of the spectral acquisition over the experimental period and the possibility of calibration transference between different devices through the same process of equalization (Hansen, 1998).

Besides obtaining the spectrum, the levels of fat, protein, casein, urea nitrogen, $\mathrm{pH}$, freezing point and somatic cells count were determined to characterize the composition of milk. Analyses were done according to the procedures recommended by the manufacturer (Foss Analytical, 2008).

As suggested by some authors (Foss Analytical, 2008; Hansen, 1998; Soyeurt et al., 2009), the spectrum region between 963-1,580, 1,715-1,812 and 2,698-2,968 $\mathrm{cm}^{-1}$ were considered for the construction of calibration. The region related to absorption of water molecules (1,584-1,712 and above of 2,968 $\mathrm{cm}^{-1}$ ) and the region between 1,815-2,694 $\mathrm{cm}^{-1}$, which does not provide meaningful information to the matrix milk, were removed.

After spectrum treatment, multivariate analysis of partial least square (QMP), through the software WinISI (WinISI, 2009), was used for the development of calibrations. For each adulterant, a calibration to predict concentration was developed and, for performance verification of each calibration, the coefficient of determination between predicted and real value $\left(\mathrm{R}^{2}\right)$, standard error of estimation (Se) and detection limit (LD) were calculated.

The impact of the addition of adulterants on the variables of milk composition, $\mathrm{pH}$ and cryoscopy was verified through Dunnett's test $(\mathrm{p}<0.05)$, using the statistical package SAS (SAS, 2003), comparing the control treatment with the others.

For validation of the calibrations, 60 samples were collected from other farms which were not used in the step of calibration development. Sampling procedures were the same previously described.

Adulterants were added at the following concentrations: 0.03 ; 0.06 ; 0.10 and $0.12 \%$ for sodium bicarbonate; 0.02 ; $0.04 ; 0.06$ and $0.08 \%$ for sodium citrate; and 5, 10 and $20 \%$ for whey, also following the same preparation procedures used in the step of development of calibration. Likewise, the statistical parameters $\left(\mathrm{R}^{2}\right.$, Se and $\mathrm{LD}$ ) for each adulterant were calculated considering only the validation samples.

\section{Results and Discussion}

The spectrum variation (Figure 1) reflected in the results of the composition, somatic cells count (SCC), $\mathrm{pH}$ and cryoscopy (Table 1), similarly to what was observed in other surveys in the same regions. Machado \& Cassoli (2008) observed coefficients of variation of 15.5 and $108 \%$ for fat, protein and SCC, respectively, in a survey conducted with approximately 25,000 farms in the years of 2007 and 2008 (Machado \& Cassoli, 2008; Mesquita et al., 2008; Souza et al., 2008). These characteristics indicate that the samples selected were representative of the area of study (Table 1).

The addition of sodium bicarbonate did not affect the results of fat, protein, casein or total solids; however, when used in fraud to neutralize the acidity of milk, this product 


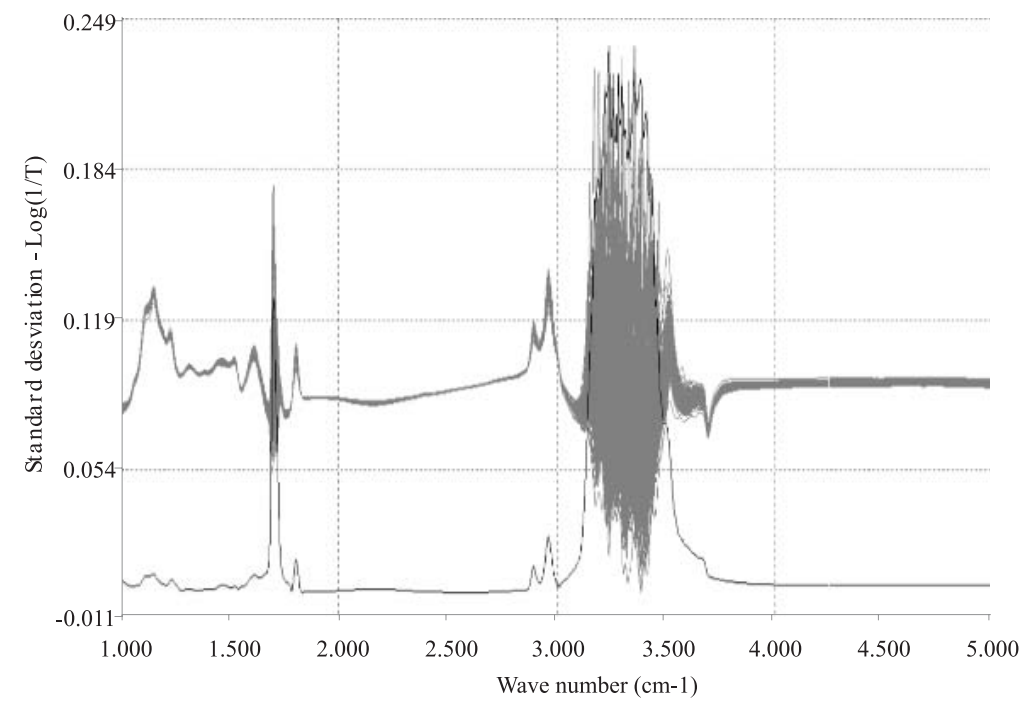

Figure 1 - Spectral variability of 100 samples (gray lines) and standard deviation at different wavelengths (black line).

Table 1 - Composition, freezing point, pH and somatic cells count (SCC) of milk samples containing adulterants

\begin{tabular}{|c|c|c|c|c|c|c|c|c|c|c|c|}
\hline \multirow[t]{2}{*}{ Variable } & \multirow{2}{*}{$\begin{array}{l}\text { Control } \\
\text { average }\end{array}$} & \multirow{2}{*}{$\begin{array}{l}\text { Control } \\
\text { CV (\%) }\end{array}$} & \multicolumn{3}{|c|}{ Sodium bicarbonate (\%) } & \multicolumn{3}{|c|}{ Sodium citrate (\%) } & \multicolumn{3}{|c|}{ Whey (\%) } \\
\hline & & & 0.05 & 0.10 & 0.15 & 0.025 & 0.05 & 0.075 & 5 & 10 & 20 \\
\hline Fat $(\% \mathrm{~m} / \mathrm{m})$ & 3.67 & 10 & 3.65 & 3.65 & 3.64 & 3.65 & 3.66 & 3.65 & $3.52^{*}$ & $3.35^{*}$ & $3.01^{*}$ \\
\hline Casein $(\% \mathrm{~m} / \mathrm{m})$ & 2.48 & 14 & 2.48 & 2.47 & 2.47 & 2.49 & 2.49 & 2.49 & $2.38^{*}$ & $2.28^{*}$ & $2.07^{*}$ \\
\hline Solids $(\% \mathrm{~m} / \mathrm{m})$ & 12.34 & 4 & 12.32 & 12.33 & 12.36 & 12.34 & 12.35 & 12.36 & $12.06^{*}$ & $11.80^{*}$ & $11.27^{*}$ \\
\hline Urea nitrogen (mg/dL) & 13.6 & 27 & $11.4^{*}$ & $9.1^{*}$ & $2.2^{*}$ & 13.5 & 13.7 & 14.1 & 13.2 & 13.1 & 12.5 \\
\hline $\mathrm{pHr}$ & 6.69 & 1 & $6.79^{*}$ & $6.84^{*}$ & $6.95^{*}$ & 6.69 & 6.70 & 6.69 & 6.67 & 6.65 & 6.65 \\
\hline SCC (thousand cell/mL) & 723 & 72 & 708 & 694 & 683 & 720 & 713 & 705 & 715 & 702 & 676 \\
\hline
\end{tabular}

* There is a difference between control and adulterant (Dunnett, $\mathrm{p}<0.05$ ).

necessarily promotes the elevation of $\mathrm{pH}$ (Augustin, 2000; Martins et al., 2008). This result was only observed in the analysis by the reference method $(\mathrm{pHr})$, but not in the results obtained by FTIR. Also, a decrease in urea nitrogen was observed with the increasing levels of addition of sodium bicarbonate; at the concentration of $0.10 \%, 15 \%$ of samples tested negative for the component and $28 \%$ of the samples at the concentration of $0.15 \%$. This suggests that the adulteration can affect the region of the spectrum related to the calibrations of urea nitrogen and pH of FTIR, and thereby cause changes in prediction and nonrepresentative results. The freezing point acted as expected with reduction in the values as the level of addition increased (Cerdán et al., 1992).

Moreover, with the addition of sodium citrate, no changes in milk composition and $\mathrm{pH}$ were observed, only a reduction of the freezing point. This finding was also reported by authors who assessed the impact of inclusion of citrate as a stabilizer of casein in industrial process (McMahon et al., 1991; Udabage et al., 1998; Pastorino et al., 2003).
The adulteration with whey caused a decrease in the concentration of all milk components, which can be explained by the centesimal profile of this matrix (Teixeira \& Fonseca, 2008). The whey used in this study was a non-acid whey and, therefore, the $\mathrm{pH}$ was expected to remain unchanged.

The correlation between the expected and predicted values for each of the adulterants is presented in Figures 2, 3 and 4 for the samples used in the development of calibration (a) as well as for the validation samples (b), respectively. The calibration developed for sodium bicarbonate showed the best performance (Table 2), both in the initial calibration and validation, with $\mathrm{R}^{2}$ higher than 0.98 . For the validation samples, the accuracy measured by the standard error of estimation was 0.007 , and the detection limit, $0.015 \%$. Studies show that the bicarbonate is added in concentrations ranging from 0.01 to $0.05 \%$ (Augustin, 2000; Martins et al., 2008) and the method of acid Rosol, considered a reference method in Brazil (Brasil, 2006), has detection level of approximately $0.02 \%$ (Paradkar et al., 2001). The accuracy (Se) of 0.007 was also similar to the reference method (Sommerfeld, 1901). 

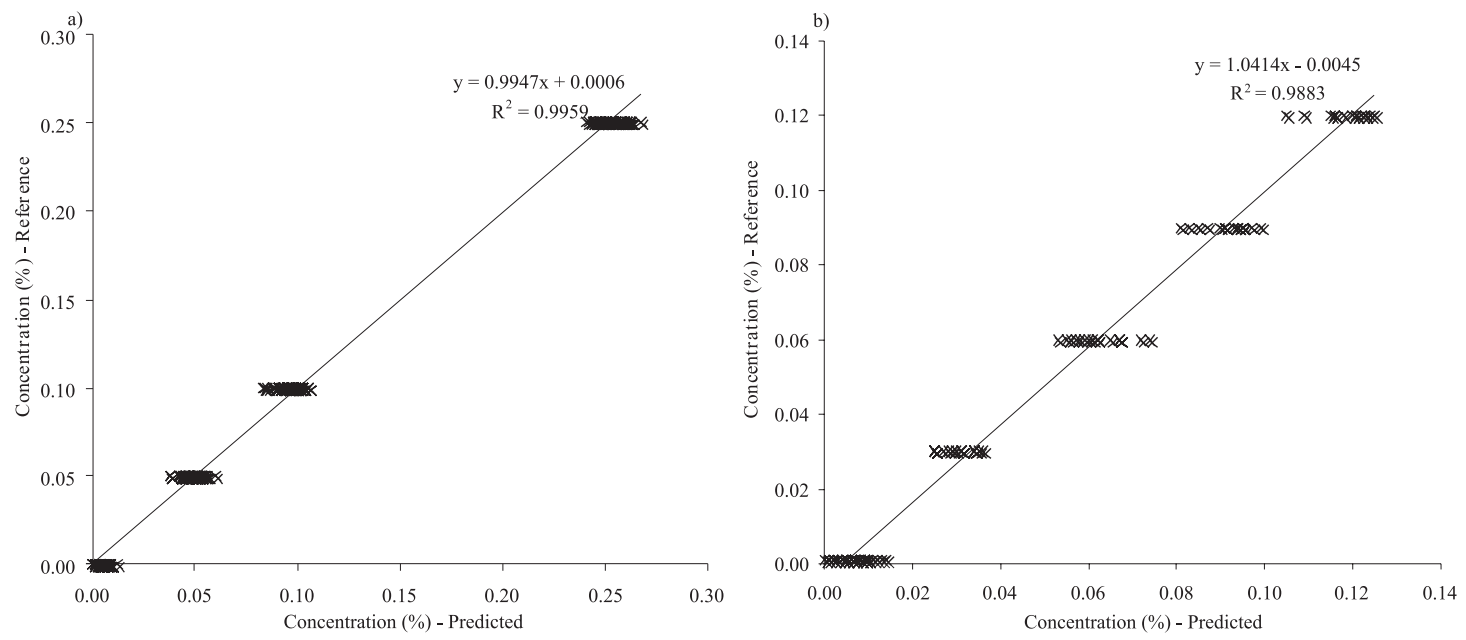

Figure 2 - Relationship between predicted values and the reference for sodium bicarbonate (SB) in samples used in the development (a) and validation of calibration (b).
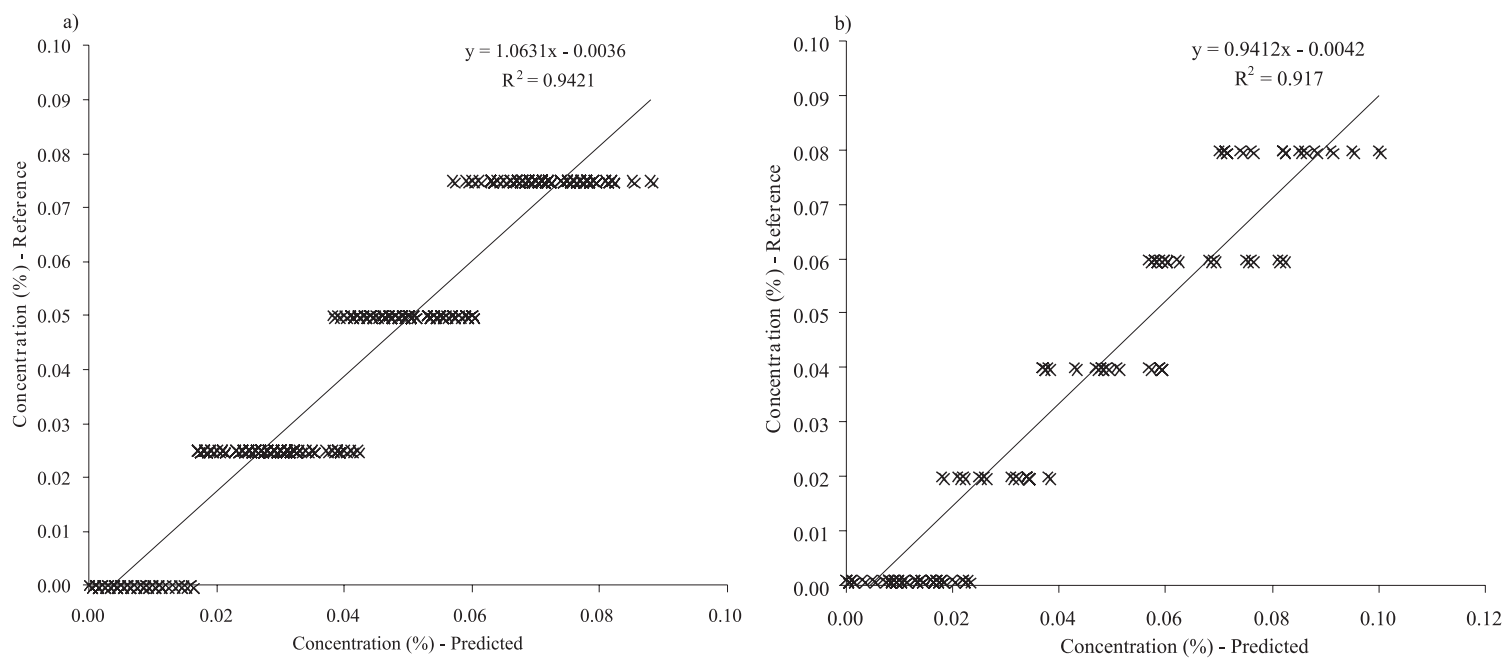

Figure 3 - Relationship between predicted values and reference for sodium citrate in samples used in the development (a) and validation of calibration (b).
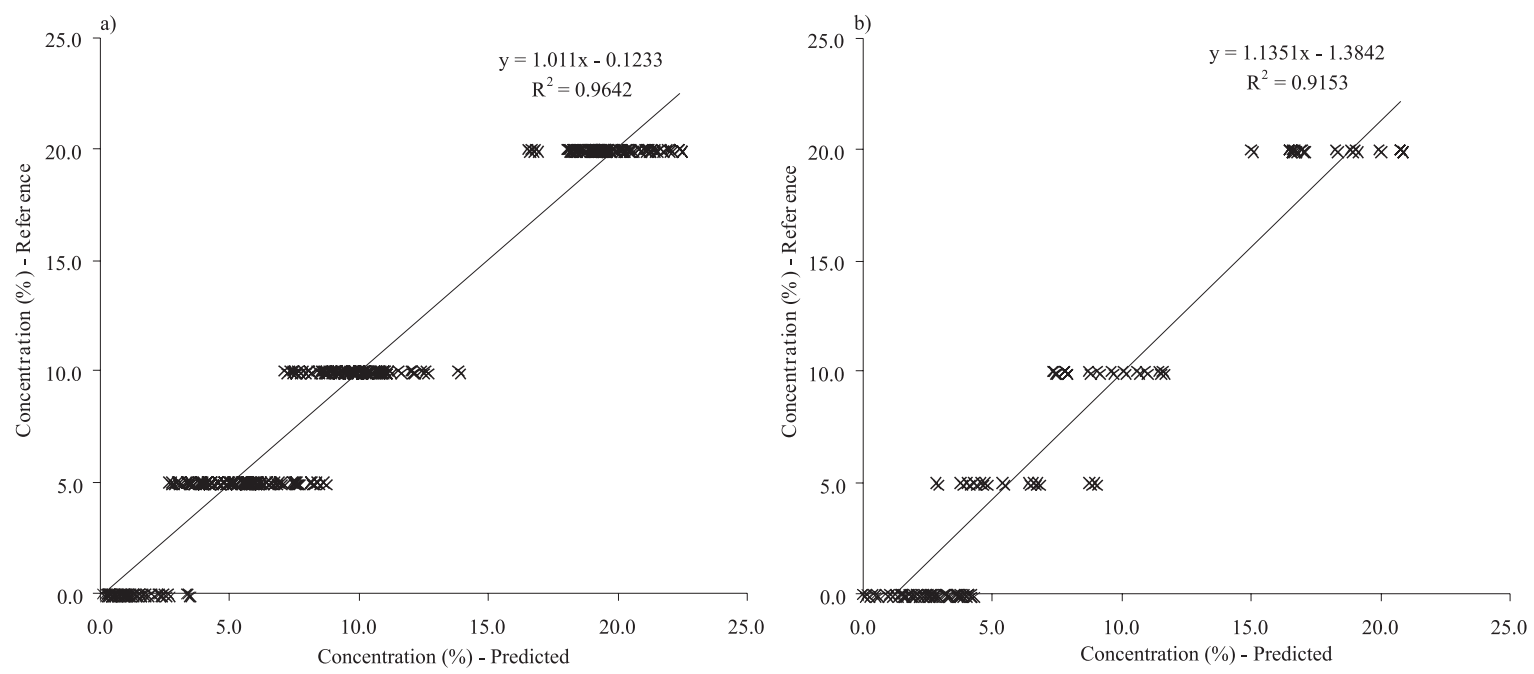

Figure 4 - Relationship between predicted values and the reference for whey in samples used in the development (a) and validation of the calibration (b). 
Table 2 - Performance of calibrations developed to predict the concentration of sodium bicarbonate, sodium citrate and whey

\begin{tabular}{|c|c|c|c|c|c|c|}
\hline \multirow[t]{2}{*}{ Adulterant } & \multirow[t]{2}{*}{ Calibration } & \multirow[t]{2}{*}{$\mathrm{R}^{2}$} & \multirow[t]{2}{*}{ Se $(\%)$} & \multirow[t]{2}{*}{ DL (\%) } & \multicolumn{2}{|c|}{ Linear equation } \\
\hline & & & & & Inclination & Intercept \\
\hline Sodium bicarbonate - $\% \mathrm{~m} / \mathrm{v}$ & Initial & 0.99 & 0.007 & 0.012 & 1.063 & -0.003 \\
\hline \multirow[t]{2}{*}{ Sodium citrate $-\% \mathrm{~m} / \mathrm{v}$} & Initial & 0.94 & 0.005 & 0.009 & 0.994 & 0.000 \\
\hline & Validation & 0.92 & 0.009 & 0.017 & 0.941 & -0.004 \\
\hline
\end{tabular}

The individual prediction interval would be 0.037 to $0.063 \%$ for target concentration of $0.05 \%$.

The same way, the calibration for sodium citrate showed $\mathrm{R}^{2}$ of 0.92 with a detection of $0.017 \%$ and accuracy (Se) of 0.009. The Ministério de Agricultura (MAPA) has recently validated (Brazil, 2009) the machine CL 10 for quantitative analysis of citrate in milk and the LD was set at $0.010 \%$. Other methods developed for determination of citrate in milk reported detection limit between 0.01 and $0.025 \%$ (Babad \& Shtrikman, 1951; Mutzelburg, 1979). With accuracy lower than the one observed for sodium bicarbonate, for target concentration of $0.05 \%$, the individual prediction interval would be 0.027 to $0.073 \%$.

Citrate is used as a stabilizer of casein in different industrial processes, and its use is allowed for this purpose (McMahon et al., 1991; Pastorino et al., 2003). In the production of UHT (ultra high temperature) milk, the maximum addition permitted is $0.02 \%$. Moreover, its use is not allowed in raw milk, what has been reported in the literature (Veloso et al., 2002). In this case, the addition of citrate improves the stability of raw milk, besides correcting the freezing point after fraud with water or whey (Veloso et al., 2002). There is no detailed information of citrate concentrations generally used for adulteration of raw milk.

On the other hand, the calibration for whey showed $\mathrm{R}^{2}$ of 0.91 with a detection limit of $2.26 \%$ and accuracy (Se) of $3.9 \%$ in the validation phase and a lower performance compared with what was observed for the other adulterants. According to Veloso et al. (2002), the addition of whey to raw milk to increase the volume of sales ranges from 5 to $10 \%$. The reference method used in Brazil for this type of adulterant is the determination of concentration of GMP (glycomacropeptide) by chromatography, which shows detection limits from 1 to $2 \%$ (Brazil, 2006). This molecule is the result of the action of the enzyme rennin and is released in the whey during the production of cheese. Therefore, there is a high correlation between its concentration and the presence of whey (Furlanetti \& Prata, 2003). On the other hand, the action of psicotrophic bacteria such as Pseudomonas spp and Bacillus spp, which develop even at low temperatures $\left(4\right.$ to $10^{\circ} \mathrm{C}$ ), can also affect the concentration of macropeptides and pseudomacropeptides, causing false-positive results (Datta \&Deeth, 2001), which would be a disadvantage of the method. The calibration developed could provide accurate results when an adulteration occurs at concentrations above $10 \%$. This analysis, along with the other components of milk, especially the content of casein, could provide additional information to confirm the presence of whey. Moreover, it is known that the adulteration by addition of whey is made with acid whey which necessarily requires the use of neutralizers such as sodium bicarbonate, which could be detected by specific calibrations.

Other studies report the potential of FTIR in the identification and quantification of other adulterants in milk products. Chen et al. (2008), using infrared methodology associated with the discriminant analysis, developed the calibration that is able to differentiate milk adulterated with reconstituted milk at concentration from $0.55 \%$ adulterant. Similarly, Mauer et al. (2009) verified that melamine, a plastic polymer used in the coating of UHT milk packages, can be identified at concentration from $1 \mathrm{ppm}$ in infant dairy products by infrared methodology. When raw milk is considered, there are few studies available. Sivakesava et al. (2002) studied the use of FTIR as a rapid method for identification and quantification of residues of the antibiotic tetracycline. The authors observed a correlation between predicted and actual value between 0.90 and 0.92 , which shows the potential of the methodology to quantify compounds at concentration of ppb. However, it should be considered that only molecules that absorb energy in the wavelength range used can be identified.

\section{Conclusions}

The methodology of FTIR may be used for identification and quantification of sodium bicarbonate, sodium citrate 
and whey in raw milk. Associated with automated equipment, it is a viable option for monitoring these adulterants and has the advantages of low operational cost and high analytical performance.

\section{References}

ASHRUST, P.R.; DENNIS, M.J. Analytical methods of food authentication. New York: Blackie Academic, 1998. 350p.

AUGUSTIN, M.A. Mineral salts and their effect on milk functionality. Journal of Dairy Technology, v.55, p.61-64, 2000.

BABAD, J.; SHTRIKMAN, N. The estimation of citric acid in dairy products. Journal of Dairy Research, v.18, p.72, 1951.

BRASIL. Instrução Normativa n. 51, de 18 de setembro de 2002. Estabelece o regulamento fixar os requisitos mínimos que devem ser observados para a produção, a identidade e a qualidade do leite. Diário Oficial da República Federativa do Brasil, Brasília, Seção 1, p.13-22, set. 2002.

BRASIL. Instrução Normativa n. 68, de 12 de dezembro de 2006. Métodos analíticos oficiais físico-químicos, para controle de leite e produtos lácteos, em conformidade com o anexo desta Instrução Normativa, determinando que sejam utilizados nos laboratórios nacionais agropecuários. Diário Oficial da República Federativa do Brasil, Brasília, Seção 1, 8p., 14. dez. 2006.

BRASIL. Instrução Normativa n. 11, de 30 de abril de 2009. Métodos oficiais alternativos para análise da qualidade do leite e seus derivados, que utilizem o sistema de detecção por diferencial de $\mathrm{pH}$ e reação enzimática - CL 10 Plus. Diário Oficial da República Federativa do Brasil, Brasília, Seção 1, 12p., 4 mai. 2009.

CASSOLI, L.D.; MACHADO, P.F. Impacto de programas de valorização da qualidade sobre a CBT. Boletim do Leite, v.13, n.156, p.4-5, 2007.

CASSOLI, L.D.; MACHADO, P.F.; COLDEBELLA, A. Métodos de conservação de amostras de leite para determinação da contagem bacteriana total por citometria de fluxo. Revista Brasileira de Zootecnia, v.39, n.2, p.434-439, 2010.

CERDÁN, J.F.; PERIS-TORTAJADA, M.; PUCHADES, R. et al. Automation of the determination of hydrogen peroxide, dichromate, formaldehyde and bicarbonate in milk by flow injection analysis. Fresenius' Journal of Analytical Chemistry, v.344, n.3, p.123-127, 1992.

CHEN H-C.; HSIEH C-L.; LEE C-W. et al. Using visible/NIR spectroscopy to detect adulteration in rawmilk with Canonical variate analysis. In: INTERNATIONAL SYMPOSIUM ON MACHINERY AND MECHATRONICS FOR AGRICULTURE AND BIOSYSTEMS ENGINEERING (ISMAB), 4., 2008, Taichung, Taiwan. Proceedings... Taichung, 2008. p.13-18.

DATTA, N.; DEETH, H.C. Age gelation of UHT milk: a review. Instituition Chemical of Engineers, v.79, p.197-210, 2001.

FOSS ANALYTICAL. MilkoScan 6000 FT+: Operator's manual. Dinamarca, 2008. 90p.

FURLANETTI, A.; PRATA, L.F. Free and total GMP (glycomacropeptide) contents of milk during bovine lactation. Ciência e Tecnologia dos Alimentos, v.23, p.121-125, 2003.

GUNASEKARAN, S.I.; IRUDAYARAJ, J. Optical methods: visible, NIR, and FTIR Spectroscopy. Madison: CRD Press, 2000. 423p.

HANSEN, P.W. Urea determination in milk using Fourier Transform Infrared Spectroscopy and multivariate calibration. Milk Science International, v.53, p.251-255, 1998.

HARDING, F. Adulteration of milk. In: HARDING, F.; CHAPMAN, H. (Eds.). Milk quality. Wiltshire: 1995. p.60-95.

KAROUI, R.; DE BAERDEMAEKER, J. A review of the analytical methods coupled with chemometric tools for the determination of the quality and identity of dairy products. Food Chemistry, v.102, p.621-640, 2007.
LEIFIER, D.; GRAPPIN, R.; POCHET, S. Determination of fat, protein, and lactose in raw milk by Fourier Transform Infrared Spectroscopy and by analysis with a conventional filter-based milk analyzer. Journal of AOAC International, v.79, p.711-717, 1996.

MACHADO, P.F.; CASSOLI, L.D. Diagnóstico da qualidade do leite na região Sudeste entre 2005 e 2008. In: CONGRESSO BRASILEIRO DE QUALIDADE DO LEITE, 3., 2008, Recife. Anais... Recife: CCS Gráfica e Editora, 2008. v.3, p.187-189.

MARTINS; M.E.P.; NICOLAU, E.S.N.; MESQUITA, A.J. et al. Qualidade de leite cru produzido e armazenado em tanques de expansão no estado de Goiás. Ciência Animal Brasileira, v.9, n.4, p.1152-1158, 2008.

MAUER, L.J.; CHERNYSHOVA, A.A.; HIATT, A. et al. Melamine detection in Infant Formula Powder Using Near- and MidInfrared Spectroscopy. Journal of Agricultural and Food Chemistry, v.57, p.3974-3980, 2009.

McMAHON, D.J.; SAVELLO, P.A.; BROWN, R.J. et al. Effects of phosphate and citrate on the gelation properties of casein micelles in renneted ultra-high temperature (UHT) sterilized concentrated milk. Food Struct, v.10, p.27-36, 1991.

MESQUITA, A.J.; NEVES, R.B.S.; BUENO, V.F. A qualidade do leite na região Centro Oeste e Norte do Brasil avaliada no laboratório de qualidade do leite, Goiânia - GO. In: COMGRESSO BRASILEIRO DE QUALIDADE DO LEITE, 3., 2008, Recife. Anais... Recife: CCS Gráfica e Editora, 2008. v.3. p.11-21.

MUTZELBURG, I.D. An enzymatic method for the determination of citrate in milk. Australian Journal of Dairy Technology, v.34, p.82-84, 1979.

PARADKAR, M.M.; SINGHAL, R.S.; KULKARNI, P.R. An approach to the detection of synthetic milk in dairy milk: 3 . Detection of vegetable oil and sodium bicarbonate. International Journal of Dairy Technology, v.54, n.1, p.34-35, 2001.

PASTORINO, A.J.; HANSEN, C.L.; McMAHON, D.J. Effect of salt on structure-function relationships of cheese. Journal of Dairy Science, v.86, p.60-69, 2003.

SIVAKESAVA, S.; IRUDAYRAJ, J. Rapid determination of tetracycline in milk by FT-MIR and FT-NIR spectroscopy. Journal of Dairy Science, v.85, p.487-493, 2002.

SOMMERFELD, P. Methods for the examination of milk for chemists, physicians and hygienists. Translated by PETERS, A.T. and HILTNER, A.M.R.S. Chicago: Alex and Eger, 1901. 96p.

SOUZA, G.N.; BRITO, M.A.V.P.; LANGE, C.C. Qualidade do leite de rebanhos bovinos localizados na região Sudeste: Espírito Santo, Minas Gerais, Rio de Janeiro, Janeiro/2007 a Julho/ 2008. In: CONGRESSO BRASILEIRO DE QUALIDADE DO LEITE, 3., 2008, Recife. Anais... Recife: CCS Gráfica e Editora, 2008, v.3. p.187-189.

SOYEURT, H.; BRUWIER, J.; ROMNEE, N. et al. Potential estimation of major mineral contents in cow milk using midinfrared spectrometry. Journal of Dairy Science, v.92, n.6, p.2444-2454, 2009.

STATISTICAL ANALYSES SYSTEM - SAS. SAS/STAT user's guide 9.3. Cary: 2003. (CD-ROM).

TEIXEIRA, L.V.; FONSECA, L.M. Perfil físico-químico do soro de queijos mozarela e minas-padrão produzidos em várias regiões do estado de Minas Gerais. Arquivo Brasileiro de Medicina Veterinária e Zootecnia, v.60, n.1, p.243-250, 2008.

UDABAGE, P.; AUGUSTIN, M. A.; McKINNON, I. R. Effects of mineral salts on renneted milk gels. Journal of Dairy Technology, v.53, p.139, 1998 .

VELOSO, A.C.A.; TEIXEIRA, N.; FERREIRA, I.M.P.L.V.O. et al Detecção de adulterações em produtos alimentares contendo leite e/ou proteínas lácteas. Química Nova, v.25, n.4, p.609-615, 2002.

WinISI IV Software. User's manual. Florida: Intrasoft, 2009. 254p. 